\title{
Vertical Electrical Sounding Analysis for Local Subsurface Water Bearing Identification Due to Isolated Hill. Case-study: Madurejo Village, Prambanan District, Yogyakarta Province, Indonesia
}

\author{
Eddy Hartantyo* \\ Geophysics Laboratory, Physics Department, Universitas Gadjah Mada \\ Bulaksumur, Yogyakarta, 55281, Indonesia \\ *hartantyo@gmail.com
}

\begin{abstract}
In a subsurface aquifer, there is a 'barrier like' phenomenon that blocks the flow of water. It will create a subsurface water bearing/dam and potential source for water well drilling. The existence of clay-limestone in the isolated hill in Madurejo village, Prambanan district, Yogyakarta seems to act like a natural groundwater body which is interesting to be analyzed by means of vertical electrical sounding (VES). For this purpose, three VES points measured with 150 meters apart, creating a line from south to north. Maximum distance for AB is 200 meters. We found the shallow unconfined from surface to $4 \mathrm{~m}$ depth and confined aquifers from $6 \mathrm{~m}$ to $29 \mathrm{~m}$. The geometry of the second aquifer in combination with the existence of isolated hill seems to have a water-bearing structure which is very potential for water resources.
\end{abstract}

Keywords: Groundwater body, VES, water-bearing.

\section{INTRODUCTION}

In the volcanically-active areas where Recent and up to Tertiary sediments laid, usually have flat layered sediments. It consists of layered sand, sandy clay, or conglomerate which may be identified for aquifers. Due to the volcanic eruption, there are several tuff or dacite sediments covering the area in the form of ash, debris, or clay-lahars as non-aquifers layers. Some coarser grain might depend on the supported materials from other cracked fresh rocks or volcanic activity ${ }^{[1]}$. At this condition, some sand layers can be nominated as aquifers if there are water infiltrations fulfilling the porous part of these layers.

The isolated hill, faults, and high basement usually act as a subsurface water barrier if these bodies/planes are blocked the aquifer flow and called as a water-bearing structure. This tend to act like a sub surfaces dam. The geometry, aquifer thickness-depth, and lithology determination of this water bearing are very important properties for finding the prospect of the boring locations for subsurface fresh water.

In the Specific Region of Yogyakarta, Indonesia ${ }^{[2]}$, there are some areas which geologically and hypothetically have these properties (see Fig. 1). Water is flow from higher topography (Merapi volcano) in the northern area, and going relatively to the south direction. The existence of limestone in the south-west part, the volcanic intrusion in the north-west part, the up revealed metamorphic basement in the north-east, the laying east southern mountain ridge, and some clay-limestone isolated hill in the center (pointing with $\mathrm{O}$ ), are all creating the natural dams for subsurface water. 
The tertiary sediments filling in the Yogyakarta basins consist of sand, sandy clay, tuff, agglomerate and ash layers ${ }^{[2]}$. The sand layers are supposed to be an aquifer and used extensively as drink water consumption for the people in Yogyakarta. There are three aquifer layers in Yogyakarta ${ }^{[3]}$ : the first, the shallow layer which is unconfined with various depths from $0 \mathrm{~m}$ to 15 meter ${ }^{[4]}$, the the second, the middle layer, with the depths from 70 meters to 80 meters ${ }^{[5]}$, and the third, the deepest layer with the depth of more than 120 meters.

7³8'31.9"S $110^{\circ} 46^{\prime} 13.9^{\prime \prime} \mathrm{E}$

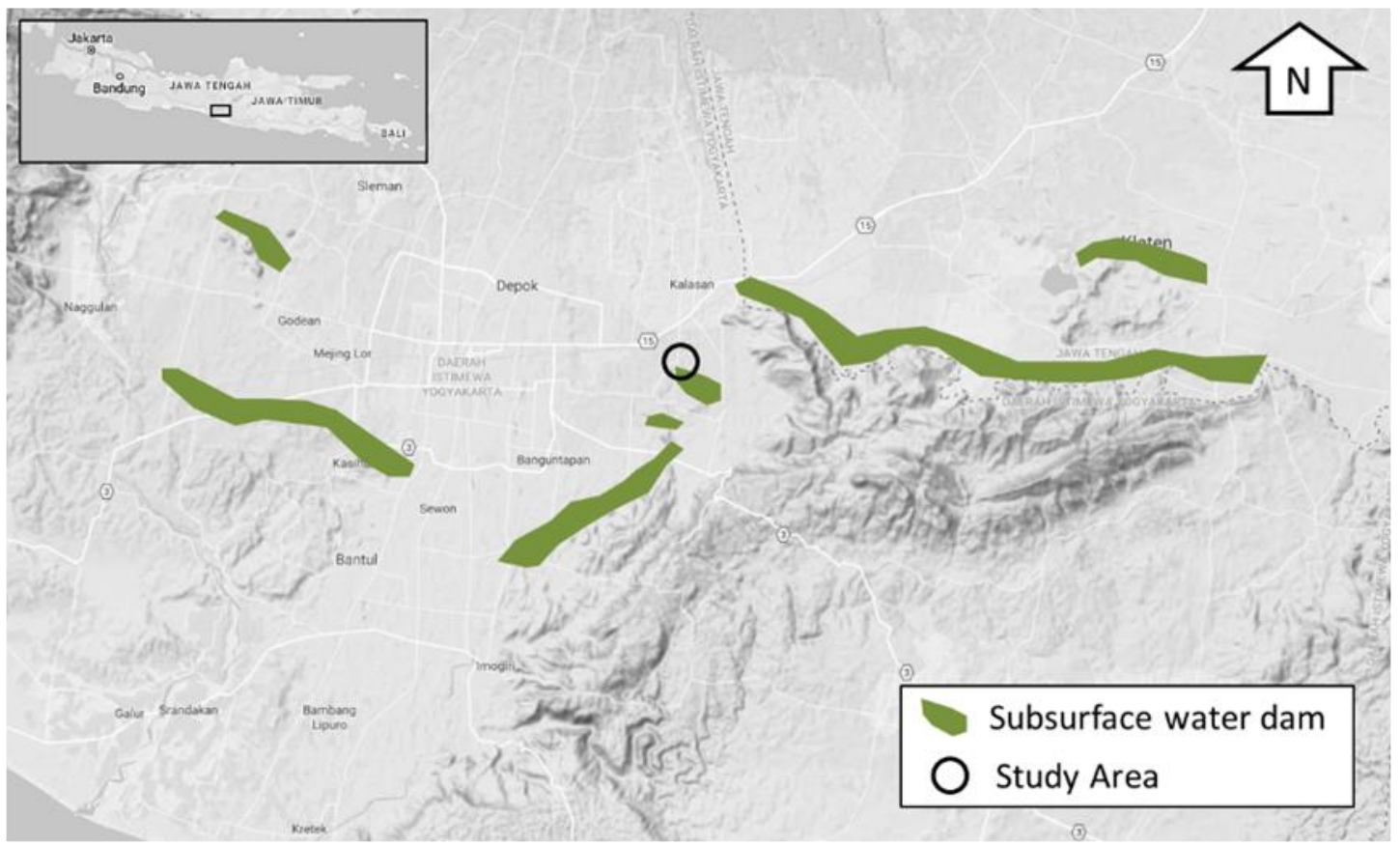

800'28.3"S $110^{\circ} 06^{\prime} 09.9^{\prime \prime} \mathrm{E}$

Figure 1. Areas (dark green) which geologically and hypothetically are deducted for being a subsurface water dams in Yogyakarta. Black circle shows the location of research area

The first aquifer usually is used by people for the daily purposes by shallow surface wells. This aquifer is being affected by season ${ }^{[4]}$. The second aquifer is pumped for middle to high levels of buildings, such as water communities (privates), hotels, apartments, hospitals, etc. The usage of the third aquifer has not been reported yet. The existence of subsurface water dam (water bearing) will provide the maximum subsurface water storage. Due to this importance, understanding the geometry (aquifer depth and thickness) of this dam is very vital.

One of geologically possible subsurface water bearings is located in the area of Madurejo village, Prambanan district, Yogyakarta province (shown with circle mark O in Fig 1). The west part of this village is covered by rice fields and the south part is bordered with a small isolated hill. The surface water is plentiful, delivered from a good irrigation. To know the subsurface layers, the vertical electrical sounding (VES) was conducted in only three points, elongated from south to north (see Fig. 2). The distance between each point was set to around 150 meters and settled as a lineament parallel with the rice field footpath towards a relatively north-south direction. The use of the VES as a tool for this purpose is very familiar since it has widely been used up to recent surveys/projects $[6,7,8,9]$. 


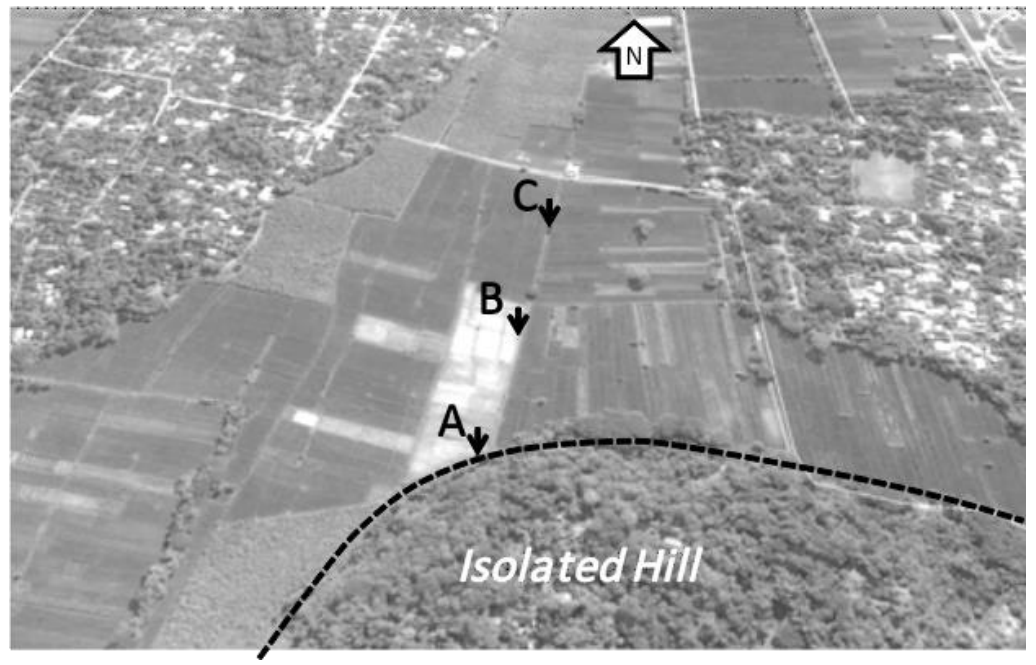

Figure 2. The aerial view (google earth) of study area from the south above the isolated hill. Three VES points are denoted with $\mathrm{A}, \mathrm{B}$, and $\mathrm{C}$, with approximately 150 meters spacing

\section{METHODS}

The vertical electrical sounding (VES) was conducted with Schumberger geometry. This geometry has a great acceptances due to lateral inhomogeneity and to economically possessing simple electrode movements ${ }^{[10]}$. Four electrodes were used, two electrodes were used as sink and sources, and another two were for measuring the potential difference. The sink and source electrodes were located at the outer part of the measuring lines, and potential electrodes were plugged in between these electrodes. The maximum eccentricity of this Schlumberger array was applied for $1 / 5$, following the chart with (9 to 10) points per decade. Due to the existence of clay in the near surface, a relatively high current, at least $20 \mathrm{~mA}$, was used.

The measured potential difference was then used for calculating the apparent resistivity at that configuration by using Equation (1) ${ }^{[10]}$ :

$$
\rho_{\mathrm{a}}=\frac{\pi L^{2}}{2 s}\left(\frac{V_{M N}}{I}\right)
$$

where, $L$ is the distance of sink-source (AB, in meter), $s$ is the distance of potential electrodes $\left(M N\right.$, in meter), $V_{M N}$ is measured potential difference (in $\mathrm{mV}$ ) and $I$ is the amount of transmitted current (in $\mathrm{mA}$ )

For converting the apparent resistivity to be one-dimensionally-layered true resistivity, the inversion software was used. For each measured points, the one-dimensional (in depth direction) resistivity profile was used for this, consisting of modeled layers with their respective resistivity and thickness.

\section{RESULT AND DISCUSSION}

The plot of VES data is shown in Fig. 3. For the three point locations, apparent resistivity of points B and C looks similar. This similarity indicates that in the geoelectric senses, these two locations are similar. Point A also looks similar in shape but shows smaller apparent resistivity. This lower resistivity in point $\mathrm{A}$ indicates the high influence of impermeable of isolated hill which consists of clay and wet limestone.

VES inversion of the three dataset shows the true resistivity versus depth, which has been interpreted in their respected hydrogeology (see Fig. 4). The point A, lying near the isolated 
hill, shows smaller resistivity in the range below $15 \Omega \mathrm{m}$ in almost all depths. A higher resistivity found in the very near surface is interpreted as sand filled with water content, from surface up to $1 \mathrm{~m}$ depth, which is exactly similar to the evidence of small pond near point A. Very low resistivity is interpreted as the wet clay with very low porosity.

The VES inversion of points B and C shows a similar feature (Fig. 4). We interpret the two aquifer layers to have the resistivity range of $50 \Omega \mathrm{m}$ to $100 \Omega \mathrm{m}$. Similar resistivity value $(55.0 \Omega \mathrm{m})$, thickness $(3 \mathrm{~m}$ to $4 \mathrm{~m})$ and surface depth (1 $\mathrm{m}$ from surface) are found at the first shallow aquifer. We infer that this might be composed from lithologically similar sands. Due to open connection with surface in the south area between points B and A, this shallow aquifer might be unconfined.

The second aquifer can also be inferred from points B and C (see Fig. 4), showing similar top-depth from surface $(6 \mathrm{~m})$ but slightly thinner in the south direction (point B up to 20 meters, and point $C$ up to 23 meters). The resistivity value of this layer is lower in the south part, indicating that the clay content of this sand layer might be higher in the south part. When the subsurface water is flowing from the north to the south region, the smaller part of clay size particles might be trapped in the sand layer at the subsurface area of point $\mathrm{B}$. The clay content might give a lower resistivity value in bulk material, due to very small resistivity values of wet clay in nature.

Comparing the two different results, point A shows only one thin surface aquifer, and a near surface aquifer, and points $\mathrm{B}$ and $\mathrm{C}$ show two thick aquifer layers. Therefore, we can see that there is a barrier in subsurface (see Fig. 4). The barrier acts like a dam or water-bearing which stops the flow of water through aquifer layer. The position of water bearing is somewhere between point $\mathrm{A}$ and $\mathrm{B}$. This also shows that the isolated hill in the south of Madurejo village acts like a subsurface water bearing. From this case, we can propose for water drilling between point $\mathrm{B}$ and $\mathrm{C}$ up to 20 meters depth.

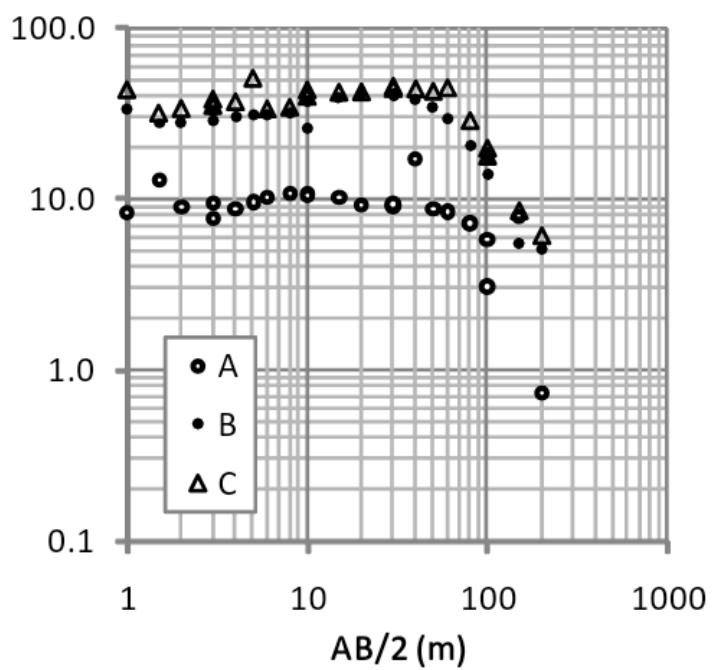

Figure 3. The bi-log plot of VES data for three point locations. $A B / 2$ is the half distance of sink-source electrodes 


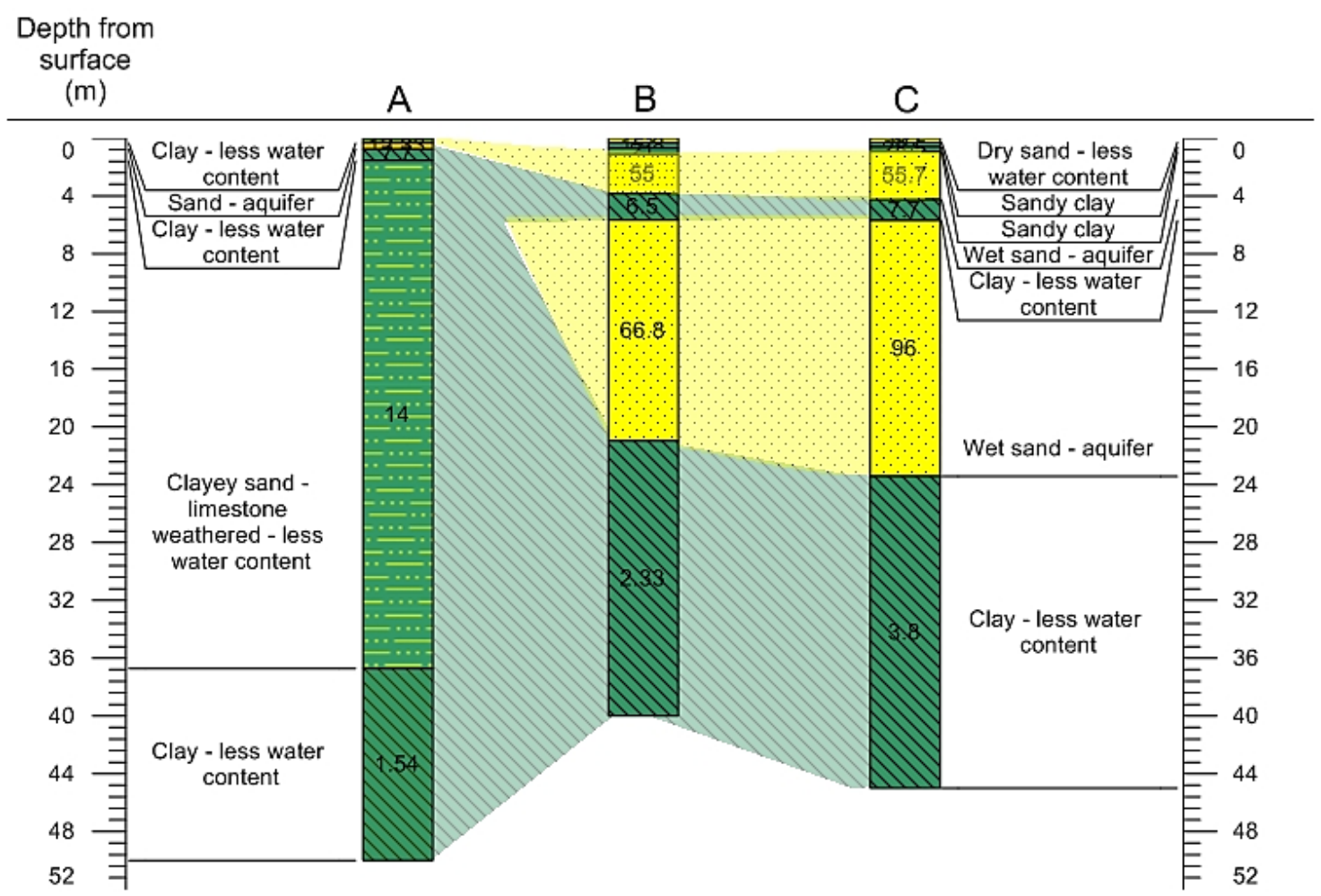

Figure 4. Interpretation of profile A, B and C. The shallow water table is lying at $1 \mathrm{~m}$ to $4 \mathrm{~m}$ in B and C, and it is shallower in A. The water bearing phenomenon can be seen in the shape of interpreted layer around $\mathrm{A}$, marked as claye sand-weathered limestone

\section{CONCLUSIONS}

The subsurface water bearing caused by natural groundwater body can be identified from the VES survey. The second aquifer is shown to be thin in the south direction, where the isolated hill exists. The water barrier exists somewhere between point $\mathrm{A}$ and point $\mathrm{B}$, and it is proposed that for water drilling the area between point $\mathrm{B}$ and point $\mathrm{C}$ is appropriate. Understanding the water bearing might be re-measured by using a deep profil of geoelectric tomography for better results.

\section{ACKNOWLEDGEMENT}

The author extend special thanks to the crew (Angga and Yan) of this survey for helping conduct the VES campaign, to the head of local village and people for permission, and also to unanimous reviewers for reviewing this manuscript.

\section{REFERENCES}

1 Karnawati, D., Pramumijoyo, S., \& Hendrayana, H. 2006. Geology of Yogyakarta, Java: The dynamic volcanic arc city. In: The 10th IAEG International Congress, Paper number 363, Shayan, A (Ed.), IAEG Conference Proceeding, The Geological Society of London, Nottingham, United Kingdom.

2 Rahardjo, W., Sukandarrumidi., \& Rosidi, H. M. D. 1995. Peta Geologi Lembar Yogyakarta, Jawa [Geological Map of The Yogyakarta Sheet, Jawa], Pusat Penelitian dan Pengembangan Geologi LIPI, Bandung, Indonesia (in Bahasa Indonesia). 
3 Hendrayana, H. 1993. Hydrogeologie und Grundwassergewinnung im Yogyakarta Becken, Indonesien [Hydrogeology and Groundwater Production in the Yogyakarta Basin, Indonesia], [Ph.D Thesis], Technischen Hochschule Aachen (in Germany).

4 Hartantyo, E., Brotopuspito, K. S., Sismanto., \& Waluyo, 2014. Correlation of shallow groundwater levels with the liquefaction occurrence cause by May 2006 earthquake in the south volcanic-clastic sediments Yogyakarta, Indonesia. International Journal of Applied Sciences 5: 1-8.

5 Hartantyo, E. 2012. VES Geolectric Report to Cavinton Hotel, Yogyakarta, Project Report, p. 6-7.

6 Bharti, R. 2016. The Vertical Electrical Sounding (VES) procedure to delineate potential groundwater aquifers in Guna Madhya Pradesh. Imperial Journal of Interdisciplinary Research 2: 253-259.

7 Abakunov, E. 2016. Vertical electric sounding of selected arctic and antarctic soils: Advances in express field investigation of the cryosols. Geophysical Research Abstracts 18: 55.

8 Mariyanto, H., Priahadena., \& Parnadi, W. W. 2016. Application of vertical electrical sounding method to identify distribution of hot groundwater around the hotsprings in geothermal prospect area. In: ASEG-PESA-AIG 2016 25th International Conference and Exhibition - Interpreting the Past, Discovering the Future, Worrall, L. (Ed.), Australian Society of Exploration Geophysicists Adelaide, Australia.

9 Mohamaden, M. I. I., Wahaballa, A., \& El-Sayed, H. M. 2016. Application of electrical resistivity prospecting in waste water management: A case study (Kharga Oasis, Egypt). The Egyptian Journal of Aquatic Research 42: 33-39.

10 Telford, W. M., Geldart, L. P., \& Sheriff, R. E. 1990. Applied Geophysics 2nd ed., Cambridge University Press, USA. 